"Why Study Schools?" by Jeffrey Guhin forthcoming in The Handbook of Classical Sociological Theory, published by Springer and edited by Seth Abrutyn and Omar Lizardo.

\title{
Why Study Schools?
}

\section{Introduction ${ }^{1}$}

Why do we study schools? For some of us, the answer might simply be academic interest. Schools are interesting places where interesting things happen. Yet for most sociologists who study schools, we do so because we care about them, and here's what's critical: we care about schools, at least in sociology, often because we care about inequality.

Yet should inequality be the central — and sometimes nearly the exclusive-way to express academic interest in schools? This question goes back to those big theory books written in the 1970's (Collins 2019, Bowles and Gintis 1976, Bourdieu and Passeron 1977), books that Jal Mehta and Scott Davies describe as the ongoing theoretical core of our subdiscipline (Mehta and Davies 2018). Are schools sites to study inequality or are schools sites to solve inequality? Do schools legitimate inequality or work to undo it? Are they about capital or credentials? The answers to all of these questions can obviously be a bit of both (Labaree 1999), and in this chapter, I want to emphasize how a path not taken in the beginning of the sociology of education_-as exemplified in the work of John Dewey, W.E.B. Du Bois, and Emile Durkheim — could have taken us another way in the study of schools, emphasizing schools as sites of moral and political education with goods internal to them (as opposed to goods that are primarily useful in remedying inequality).

This distinction is not simply a question of one arbitrary way of thinking about schools over another. Framing schools as the primary means of redressing unjust inequality affects not only how we study schools but how we justify and explain our studies to each other and, more importantly, to those outside of the academy. By emphasizing schools as sites to solve inequality rather than actively redistributing resources and power via the state, we can inadvertently reify a meritocratic ideology that justifies the inequalities it is allegedly created to address. In what follows, I will outline some of the contemporary challenges in the sociology of education, describe the moral and political education outlined by Dewey, Durkheim, and Du Bois, and then stress how their focus on education allows us to reconsider the role of internal goods, meritocracy, and a political and economic redistribution no longer rooted in the "merit" of its recipients as determined by school achievement.

\section{The Sociology of Education and its Problems}

The sociology of education today is in many ways simply a large subsection of the sociology of stratification (Mehta and Davies 2018), with those studies of stratification emphasizing primarily inequalities of class (Owens 2018), race (Downey 2008, Owens and Lynch 2012), gender (Buchmann, DiPrete, and McDaniel 2008), and sometimes sexuality (Pascoe 2011). There are exceptions of course: some sociologists of education study organizational forms (Hallett 2010); religious experience (Guhin 2016b), or the relationship with the state (Mayrl 2016). Yet even these studies often are forced to make themselves legible to mainstream sociology of education by emphasizing stratification as the primary motivator of studying schools; either that, or these projects come to be outside of the sociology of education, whether in a different sociological subfield or in one of the various subfields in the broader academic study of education. For those research projects

1I am grateful for the opportunity to have this chapter as part of this volume, and I am especially indebted to comments from Seth Abrutyn, Omar Lizardo, and Freeden Blume Oeur. 
"Why Study Schools?" by Jeffrey Guhin forthcoming in The Handbook of Classical Sociological Theory, published by Springer and edited by Seth Abrutyn and Omar Lizardo.

that remain in the sociology of education, stratification remains central, and it seems safe to assume that these studies are motivated by a deep commitment to justice (Guhin 2016a), a sense that these inequalities are morally and politically wrong and it is academics' duty to understand these wrongs and address them.

Implicit (and sometimes explicit) in these studies about schools' relationship to a particular inequality are two much larger questions: what are schools supposed to be doing, and what do they actually do? Within the sociology of education, the answer tends to be that schools are responsible for lessening stratification, or at least they could be: there is ample disagreement about whether schools reify or remedy socio-economic stratification, and many have argued some combination of the two, with some schools making things better and some schools making things worse (Downey and Condron 2016, Mehta 2015, Raudenbush and Eschmann 2015). This ambivalence can extend to the various studies of inequality, as an increasing awareness of intersectionality (Collins and Bilge 2016) can show how schools might decrease, increase, or even reify stratified differences of race, class, gender, or sexuality at differing rates and sometimes at cross purposes (Ispa-Landa 2013). The formations of these questions and analyses are complex and multi-faceted, and so are the answers they develop.

Nonetheless, despite these complexities, the sociology of education has become a relatively coherent research program, centered around the relationship between various forms of schooling and various forms of inequality, often emphasizing unequal outcomes but sometimes also focused on synchronic experiences of inequality. This relatively coherent focus has led to something resembling what Kuhn would call normal science (1962), with a research paradigm that emphasizes a narrow set of questions, even if the possible permutations and combinations within those questions are quite broad (Stevens 2008, Brint 2013, Mehta and Davies 2018). To be clear, I am here addressing those sociologists of education employed in sociology departments who publish in the journal, Sociology of Education. Scholars of education in education schools have a much more heterogeneous experience of publishing and intellectual projects, including, in many cases, sociologists employed at education schools (even if my hunch would be that most sociologists employed at education schools are still more or less maintaining the stratification paradigm.)

The stratification paradigm by no means necessarily a problem. The sociology of education has done quite productive work, gaining media and governmental attention for its commitment to understanding inequality. Yet there are a few potential challenges to this approach. The first, and most obvious, is that the sociology of education's primary focus on schools as sites to study inequality runs the risk of implicitly arguing that schools should be the primary site to solve inequality. Now whether or not schooling is the best way to combat inequality is a separate question (though I am convinced it is not). However, the important point here is that studying schools as a means of remedying inequality at least potentially privileges the purpose of schools as being about the remedying of inequality, at the expense of other, much broader means of remedying inequality. This seems to me as much the concern of individual sociologists as it is a function of large grant-making organizations emphasizing the role of schools in remedying inequality, though the latter can obviously have a habituation effect on the former.

This moves to the second problem of the contemporary sociology of education's focus. If schools are really interesting because of the later socio-economic outcomes they produce, then what good is the experience of schools themselves? In other work (Guhin and Klett 2018), I have described how the sociology of education can over-emphasize the "external goods" of schooling, that is, the goods 
published by Springer and edited by Seth Abrutyn and Omar Lizardo.

one gains from having done schooling rather than the goods internal to schooling itself. Is math good because you'll do well on a test you need to pass to get into college or get a good job? Or is math good because of something intrinsic to the experience of math? To emphasize so much the external goods of schools ironically runs the risk of alienating students and teachers from the internal goods of education, an experience already quite common to the extent students and teachers feel beholden to state testing regimes and standardized college readiness exams like the SAT and ACT (Au 2010). This distinction between internal and external goods is similar to the distinction between intrinsic motivation and extrinsic motivations studied in education research (Covington 2000), with the important distinction that motivation is primarily about an affect within the student while a "good" is more centrally located within the practice itself and how that practice is experienced, narrated, and understood by various stakeholders, though most importantly the student. Studies of unequal experiences of education do not necessarily run into this problem of ignoring internal goods, but only to the degree that the inequality in question regards something that matters as an end in itself and not as a means towards middle-class autonomy or some form of gender, racial, or sexual equality.

Finally, and perhaps most importantly, the sociology of education's commitment to justice is often at the level of aggregate individuals rather than collective obligations. In other words, the concern is not with how students act as citizens and community-members but rather how they are allowed to be agentic and capable of realizing their goals and eventual socio-economic capacities. Devastating and important work within the sociology of education has documented how long-standing organizational forms like the school-to-prison pipeline and mechanisms like student tracking have circumscribed individual students' abilities to realize their potentials, often along racialized, classed, and gendered lines (Mittleman 2018, Holm et al. 2013). Careful ethnographic work has shown how the privileged maintain their privilege in subtle and unsubtle ways (Calarco 2018, Ferguson 2001). Implicit (and often explicit) within these studies is an assertion that students have a right to a good education and a caring environment free of prejudice (or, more realistically, an environment with adults critically self-aware of the racism, sexism, and other forms of prejudice that are seemingly inextricable from large organizations). Also implicit within these studies is an overarching commitment to students' rights to agency, to a capacity to move forward towards a certain vision of themselves unhampered by structures of power that are most brutal to students with disabilities, students from low-income backgrounds, students of color, queer students, immigrant students, and female students, among other marginalized identities. A concern about these students' rights is both an implicit and explicit focus in much of the sociology of education.

Yet rarely acknowledged in these studies is the corollary of rights: responsibilities. Part of a hesitation to acknowledge responsibilities comes from an important awareness of how social and civic responsibilities are often parceled out unequally: women and people of color are often expected to do the hard of work of "being nice" and "keeping up the house" in both literal and metaphorical sense of the terms (Hooker 2016, Pateman and Mills 2007). For example, some scholars have found that a while male might feel simply a responsibility to his best self, while a Black male must be his best self while also remembering his community and "staying out of trouble" or else this Black male is a failure on both counts (Eliasoph 2013). These expectations of responsibility become even more complicated as identities intersect: not only might women ask what they owe other women and the disabled what they owe to other who are disabled, but also what a woman with a disability owes to whom. These are complex questions in political and moral philosophy (Alcoff 2005, Mason 2000, Shelby 2005, Barnes 2016), yet they are rarely engaged in the sociology of education. And simply because political and moral responsibilities are parceled out unequally and unjustly does not mean 
they should cease to exist or cease to be studied. Indeed, the unequal, racialized, gendered, and classed basis of responsibilities is itself a sociological argument worth making about schools. To be clear, this is not a call for sociologists of education to become moral philosophers, but instead to recognize that there is a folk moral philosophy in every student, every teacher, and every classroom, alongside every school, every district, every piece of education policy, and even every argument within the sociology of education. In the traditions of Du Bois and Durkheim, it's worth brining an explicit awareness of the "moral background" (Abend 2014) to the study of schools.

So, as I have been describing it, the sociology of education has three important problems: first, a potential conflation of education as a site to study inequality versus as a site to solve inequality, second, a focus on external goods rather than internal goods, and third an emphasis on rights rather than responsibilities. These problems extend to a broader one, which is a general failure to engage schools as social sites in which just about every kind of social thing happens: the sociologies of sexuality and culture (Fields 2008) are just as interesting in schools as they are anywhere else, for example, yet sociological studies of schools tend to be more focused on explaining stratification rather than any other social thing. If these studies of sexuality or culture do happen in schools, they tend to foreshadow their contribution to the other subdisciplines and leave the school piece in the background, getting published in journals more related to the content (sexuality, for example) rather than the setting (schools).

The reasons for these problems are complicated, and I do not have space to engage all of them here. For what it is worth, I think the explanations are four-fold. First an isomorphic commitment to imitate economics (Berman 2011, Hirschman and Berman 2014) in an attempt to create policyrelevant work that can impress education stake-holders in funding agencies, government, and school districts. Second, and relatedly, a path-dependent insistence that schools are best studied through large quantitative studies of socio-economic outcomes. The third and fourth explanations are more ideological, though that ideology makes the first two reasons financially and organizationally attractive to many.

The third reason I suspect the sociology of education has the problems I've listed is because of the ongoing power of meritocracy as an operating myth in American life, the idea that people can rise agentically through their own merit (Arrow, Bowles, and Durlauf 2018, McNamee and Miller 2009). The myth of meritocracy functions in the sociological sense of a myth, a story that might not be technically true (indeed there is much sociological evidence against it) but that helps to orient people to the world, allowing them to make sense of themselves and their suffering. A focus on meritocracy creates a focus less on communities and more on individuals, less on redistributing income and more on how students do in schools such that they might eventually "merit" the social advancement they receive. Even if sociologist utterly reject the concept of meritocracy, they might have inherited the aggregating focus on individual outcomes that meritocracy imparts.

Yet most sociologists have not abandoned meritocracy completely inasmuch as their critique of meritocracy is nearly always an imminent one. While these criticisms are nearly always implicitly rather than explicitly described, the implication in many sociological analyses of inequality in schools is not so much that achievement is the wrong basis through which to apportion resources, merit, and status, but that how such "achievement" is narrated, understood, and developed occurs through a process which provides significantly more resources (whether material, social, or cultural) for certain students to manifest their merit. In other words, the nature of the meritocracy myth is two-fold: either a veneer or a template. there are some for whom it is a myth that functions as a veneer, 
"Why Study Schools?" by Jeffrey Guhin forthcoming in The Handbook of Classical Sociological Theory, published by Springer and edited by Seth Abrutyn and Omar Lizardo.

allowing them to insist that anyone can succeed if they work hard enough. This is rarely if ever the case for sociologists of education. Yet the sense of this myth as a template is much more powerful, and is common to virtually all sociologists of education, e.g. the idea that achievement is itself more praiseworthy than ascription, and that achievement is therefore a better basis for determining the placement of status, resources, and "merit" than other forms of distinction. Yet the problem is not so much that merit exists and is a good reason for dividing roles (LeBron James deserves to play basketball for the Lakers more than I do). The problem is how merit is determined and how various forms of merit are made to be more or less important than each other via a process Bourdieu calls symbolic violence (Bourdieu 1990). The critique of meritocracy within the sociology of education is therefore rarely a critique of merit in and of itself, but of how the designation of merit can confuse ascription and achievement, or else how a real difference in achievement (however such a claim can be made) can be used to justify vast inequalities of resources and status. The challenge for contemporary sociologists is neither to abandon the benefits of meritocracy nor to embrace a hardnosed Hobbesianism; the challenge is simply to acknowledge the implicit role of the meritocratic myth, whether understood as veneer or template, in the basis of our arguments and the implicit angle of our critiques.

The fourth reason parallels and undergirds the third, which is a general commitment to procedural liberalism (Johnston 2007, Sandel 1984, Sandel 1998) among many Americans. Procedural liberalism is best encapsulated in John Stuart Mill's harm principle (Mill 2015), the idea that people should all pursue their own interests and need not bother themselves with obligations to others. Indeed, such obligations to others might well entail commitments those others do not share! So the best thing is simply to be responsible to do no harm and let everyone figure their lives out on their own. This philosophy dovetails nicely with Adam Smith's concept of the invisible hand, a much-debated essential piece of contemporary liberalism (Harrison 2011, Smith 2010). While what Smith meant by the invisible hand remains vague, it has come to mean something like the insistence that social life will have greater efficiency and better outcomes if many different people do many different things without any central coordination. Markets are the classic example of this: if a central power insists on a certain price or a particular product, it would not be as efficient—or ultimately as good for all involved - as if many separate individuals simply showed up with their demands and supplies. Whether or not this position is always true of markets is a separate question (Hall and Soskice 2001), but the emergent power of aggregates has been extremely powerful for many spheres of American life. Something similar, I believe, can happen in schools: to the extent students are their best selves, their main responsibility has been met (Nunn 2014). All they have left to do is not harm anyone else.

While not solving all of the problems listed above, the "Stanford School" does take much more seriously the political and moral roles of schools than what I have described above. Largely a subcurrent within the sociology of education, the sociological study of institutions as outlined most prominently by John Meyer and the "Stanford School" (Boli, Ramirez, and Meyer 1985, Meyer and Rowan 2006, Meyer 1977). Most influential in the sociological study of organizations and culture, Meyer and his coauthors' insights into the nature of schooling as a global institution have emphasized how schools function as a productive force in society, helping to socialize students not only into citizens but also into individuals (Meyer 2010, Meyer and Jepperson 2000) who take seriously their institutionalized responsibilities to others and themselves. Because of the power of its institutional momentum, schooling thereby affects society itself, including in its domain even those people who are not themselves schooled or who disagree with the institutionalized values or domains schooling seeks to impart. However, with some prominent exceptions (Hallett 2010), the Stanford School has not been especially influential in the sociology of education as demarcated 
"Why Study Schools?" by Jeffrey Guhin forthcoming in The Handbook of Classical Sociological Theory, published by Springer and edited by Seth Abrutyn and Omar Lizardo.

above, even if it's importance has been much more prominent in cultural sociology, the sociology of organizations, and comparative-historical sociology. The Stanford School has also not been sensitive to the issues of race and interaction described below in the works of Du Bois and Dewey. However, it is an excellent ongoing counterfactual of what a more robustly Durkheimian sociology of education could resemble.

\section{What Might Have Been: The Three D's on Education}

Yet the sociology of education could have looked another way, and in this chapter, I will draw on two founding sociologist of education (Durkheim and Du Bois) and one cousin to the founders (Dewey) to explain how. The first two might seem obvious: Emile Durkhiem wrote extensively about education and so did W.E.B. Du Bois. John Dewey is a more heterodox choice, a writer who identified himself throughout his career as a philosopher more than anything else. Indeed, Dewey sometimes wrote about sociology dismissively (just as Durkheim wrote dismissively about pragmatism). Yet Dewey's influence on Mead (1967) and other early sociological pragmatists helped to form the tradition of symbolic-interactionism and much that still matters today in the microsociological. More recently, there has been a spate of sociological engagements with Dewey across various subfields, making an analysis of his work an important addition to any study of classical sociology (Winchester and Guhin 2019, Bargheer 2018, Joas 1996). A combination of Dewey, Durkheim, and Du Bois can help us to recognize how the sociological study of schools could look very different than it does today.

So what would a 3-D sociology of education look like? And how would that be different from the majority of the sociology of education today? Perhaps most importantly, a 3-D sociology of education would emphasize education as an explicitly moral and political institution, just as schools would be emphasized as moral and political organizations. Which gets to a second point: schools would be emphasized as things in themselves, rather than as vessels through which education in capital or credentials occurs. These first two points lead into the problems of the sociology of education we described earlier: a potential (even if inadvertent) recapitulation of a meritocratic veneer through which schooling is solution to rather than site of inequality, an emphasis on external goods over internal goods, and an emphasis on rights over responsibilities.

Of the three men often considered the "founders" of sociology, Emile Durkheim (1858-1917) was the one who most explicitly engaged the question of education. Durkheim understood schooling as a necessary agent of moral and political socialization in a rapidly changing and often chaotic world. Durkheim's writing on education was best encapsulated in a series of lectures, later published in France in 1925 and published in English as Moral Education (Durkheim 1961). Yet he wrote about schools and education throughout his career, and for reasons quite distinct from questions of socioeconomic mobility. Society, Durkheim argues, should "have before it an ideal toward which it reaches. It must have some good to achieve, an original contribution to bring to the moral patrimony of mankind" (1961: 13). Note that society for Durkheim is understood as something universally felt and experienced, which for him was partially a sociological description and partially a normative commitment, with the two distinctions never quite resolving themselves. He believed that previous systems of moral education were too static for the changes that would continue to come, possibly at the hands of these students themselves once they entered society as adults. So moral education, Durkheim felt, must not be a rigid set of unbending precepts; yet nonetheless society requires a disciplined commitment to moral life, at least through a fealty to society itself, which must be understood as more than simply the sum of its parts (1961: 60-63). Society is an entity sui generis, 
"Why Study Schools?" by Jeffrey Guhin forthcoming in The Handbook of Classical Sociological Theory, published by Springer and edited by Seth Abrutyn and Omar Lizardo.

and any moral commitment to society must be a moral commitment to society and not simply to the self. Durkheim therefore rejects the aggregating assumption that so many flourishing selves will make for a successful society.

John Dewey (1859-1952) also saw schools as socially and politically vital within a changing world. Dewey's interests in schools were broadly sociological, even if he would not have used the word: unlike Durkheim, he was uncomfortable with hard distinctions between the society and the person or, by extension, the sociological and the psychological. As a pragmatist, he felt these sorts of differentiations - whether ontological or simply analytical - were never quite right empirically. For him, the person is in the group and the group is in the person, which leads to a central pragmatist insight: individuals are only recognized and become recognized within social interactions, just as societies only become legible by looking at what specific people do within them. That pragmatist angle makes Dewey's approach to schools a middle space between a more stereotypically American focus on individual achievement and a Durkheimian focus on republican commitments to the collective. Like Durkheim, Dewey is committed to schools as agents of socialization, and also like Durkheim, a capacity for change is central to this socialization. Neither seeks a staid and conservative recapitulation of previous generations. Yet, unlike Durkheim's explicitly civic goals for schools, for Dewey, "growth" is the most important characteristic he wants for students, a growth that happens best in a democratic context. Dewey's understanding of growth is intentionally vague, as the entire point of it is less a specific quality or even a specific ability but rather the more general capacity to develop new qualities and new capacities as needed.

Finally, W.E.B. Du Bois (1868-1963) viewed schooling as simultaneously oppressive and necessary, a product of white supremacy that was nonetheless a necessary tool not only for democratic education but for the civic goals of marginalized communities, especially African Americans (Itzigsohn and Brown 2020). As with Dewey and Durkheim, Du Bois understood schools as necessary locations both for socialization into individuals and for the development of society itself, though, unlike Dewey and Durkheim, he recognized such communal socialization as directed towards sub-communities within society rather than always towards society itself as one large and functional community. Yet unlike Durkheim, both Dewey and Du Bois were very much American liberal intellectuals: both founding members of the NAACP, both prominent progressive intellectuals, and both very much concerned about issues of racial equality and its interactions with questions of social and economic justice. While there is some debate about whether it is accurate to call Du Bois a pragmatist, he was certainly deeply influenced by the early American pragmatists themselves (especially Williams James), and he shared their collective indebtedness to Hegelian philosophy (Taylor 2004). Yet if Dewey viewed questions of racial trauma as one of many ongoing problems in American history, the ongoing scourge of racism was much more central to Du Bois's analysis.

Du Bois's relationship to Black nationalism is complicated and changed throughout his career (Moses 1988), but it worth noting that he never really ruled out that a holistic, multiracial society might someday exist (even if some centuries hence), but this was not the world he or the Black students he wrote about lived within. In asking whether Black students need separate schools, Du Bois emphasized both the "negative" experiences of racism and racial exclusion that necessitate such schools but also the many contributions of the Black experiences, all of which would help to consolidate "centers of a new and beautiful effort at human education, which may easily lead and guide the world in many important and valuable respects" (Westbrook 2014: 210). One of the most famous of DuBois's contributions to education was his evaluation of the role of a "talented tenth" in "developing the Best of this race that they may guide the Mass away from the contamination and 
"Why Study Schools?" by Jeffrey Guhin forthcoming in The Handbook of Classical Sociological Theory,

published by Springer and edited by Seth Abrutyn and Omar Lizardo.

death of the Worst, in their own and other races" (Westrbrook 2014: 92). In so doing, he pushed against an insistence that African-American education should be primarily about skills training and adding only to their economic capacity, a debate best encapsulated in his ongoing disagreement with Booker T. Washington's accommodationist approaches to African-American education and partial integration. As Aldon Morris's book on Du Bois as a founding sociologist describes, this debate extended beyond politics to social science itself, with white social scientists highlighting Washington (who lacked a college degree) often in an explicit effort to diminish the Harvard-education Doctor Du Bois (2017: 8-14).

In his Niagara Movement speech, he makes clear that "when we call for education, we mean real education...we will fight for all time against any proposal to educate black boys and girls simply as servants and underlings, or simply for the use of other people. They have a right to know, to think, to aspire" (Westbrook 2014: 133). Du Bois insisted this was the case not only for Black Americans in vocational careers but those in the middle-class as well, re-evaluating his concept of the talented tenth to insist this tenth cannot content itself with simply making money: "The new generation," he said, "must learn that the object of the world is not profit but service and happiness" (Westbrook 2014: 209). This focus on "real education" is in many ways simply a commitment to the liberal arts, albeit one that is centrally aware of the importance of the African American tradition. In his ongoing criticisms of Washington, Du Bois emphasizes how this "real education" is especially important in colleges and universities for Black students, and in so doing he links Washington's dismissal of civil and political rights with Washington's dismissal of Black higher education. The two goals are linked not only in their relevance for integration but in the capacity of "real education" for Black students to create the kind of political and civic life necessary a thriving society. And in making this insistence, Du Bois links his commitment to Black education to a broader commitment to American ideals:

In failing thus to state plainly and unequivocally the legitimate demands of their people, even at the cost of opposing an honored leader, the thinking classes of American Negroes would shirk a heavy responsibility, - a responsibility to themselves, a responsibility to the struggling masses, a responsibility to the darker races of men whose future depends so largely on this American experiment, but especially a responsibility to this nation,- - this common Fatherland. It is wrong to encourage a man or a people in evil-doing; it is wrong to aid and abet a national crime simply because it is unpopular not to do so (1994: 33).

Note here the explicit articulate of the moral and political underpinnings of a critique of inequality. Du Bois has long been recognized as an important sociologist and an important philosopher, though it is his capacity as a philosopher that, I believe, can help us better understand how to emulate his sociology.

\section{The Moral and Political Spaces of Schools}

The contemporary sociology of education is profoundly aware of the political nature of schooling to the extent that politics is about the organized use of power to distribute resources, opportunities, and capital. This discussion of politics is not often explicitly framed or described as political, but there is regular reference to governmental action and public school policy affecting the experience and outcomes of young people. Yet even if there is this awareness of how students experience political effects, there is much less emphasis on how students are themselves political, that is, how they organize their own power or come to think of themselves as relating to the rest of their social world. As such, it is not surprising that civics has a relatively unimportant role in the contemporary sociology of education, and not only because it has a relatively unimportant role in American 
"Why Study Schools?" by Jeffrey Guhin forthcoming in The Handbook of Classical Sociological Theory, published by Springer and edited by Seth Abrutyn and Omar Lizardo.

education writ large (Campbell and Niemi 2016): to the extent that civics is understood as how people relate to and understand their own rights and responsibilities within a broader society, then the sociology of education is not especially interested, except inasmuch as these understandings might relate to socio-economic outcomes, such as students believing they have a right to a certain kind of education. (Civics education has a slightly more prominent place in the education literature and in political science).

Part of the problem of "civics education" is that it can come off as a conservative rearguard attempt to maintain the status quo, an insistence that if people only learned the system, the system as it stands would work. There is also an uneasy connection between civic or civil education and "civilizing" education, with a sense that students as such are not yet able to handle the complexities of civility and must be brought into in through guides that are themselves white or at least part of a system dominated through a history of white supremacy, class distinction, and earlier, a Protestant prejudice suspicious especially of Catholics and Jews.

There is a similar, even more damning critique of "moral education," and in a few senses. The first takes on what is sometimes referred to as a "deficit," the idea that students in schools-especially students of color and low-income students - are somehow deficient in their moral commitments, often as a result of insufficient moral training at home. As a result, they must be morally strengthened through their teachers' example and pedagogy, an often-racialized process of instilling certain virtues the teachers believe students need and which (it is implied) they cannot get at home. The other damning critique of moral education, like the critique of civics education, is the idea that morality — or civic participation — is itself the solution for inequality, that if only students showed more of certain virtues, then the inequality to which their families have been subjected would no longer be a problem. Grit (Duckworth 2016), for example, and its parallel concept of mindset (Dweck 2008), are virtues often described as the difference between success and failure, and it is not too hard to go from describing the importance of grit as a moral good to understanding the ongoing inequalities of American education as a series of individual moral deficiencies rather than longstanding racialized and gendered resource hoarding.

Yet these are not the only ways to talk about the political, civic, and moral lives of schools, or what schools can produce. Durkheim is probably the most explicitly nationalistic of these three thinkers, and the most committed to the development of something lacking in students. DuBois, in different ways, makes a similar complaint about the condition of students in schools, even if his immediate goal is more situated in the particular needs of Black students. Dewey views the school as, at least ideally, the quintessential site for democratic growth, entailing moral, civic, and political goals all at once. Yet for all three, there is as awareness that schools themselves provide a location that imitates society in a way that the home-deficient or not-simply cannot.

For Durkheim, it is fundamentally the school—especially the public school—which can "train the child in terms of the demands of society," something which the family "almost by definition" is unable to accomplish (1961: 19). To ensure that such moral discipline occurs, the child's moral education must begin outside of the family in elementary school, "the critical moment in the formation of moral character" (1961: 17) for which the school is the most important institutions: the family might introduce moral ideas to the child, but it is the school that "trains the child in terms of the demands of society" (1961: 19, 230-236). Dewey makes a similar point in his pedagogic creed, arguing that "the school is primarily a social institution," extending from the family but fundamentally distinct from it. The school's "best and deepest moral training is precisely that which 
"Why Study Schools?" by Jeffrey Guhin forthcoming in The Handbook of Classical Sociological Theory, published by Springer and edited by Seth Abrutyn and Omar Lizardo.

one gets through having to enter into proper relations with others in a unity of work and thought" (1940: 7-8). To the extent Du Bois engages the distinction between schools and families, he can sometimes lean towards something approaching a "deficit" model of the African-American family, albeit one entirely aware of the structural causes of these challenges. In his 1903 call for a "talented tenth," Du Bois explicitly calls for Black institutions of higher education to guide a vanguard of Black leadership that will then move the rest of the race. Regarding African-Americans in the south, Du Bois asks what "a system of education [must] do in order to raise the Negro as quickly as possible in the scale of civilization" (105). The school-especially the African American university - is a key component of this process. To be clear, Du Bois is not always so harsh to Southern African-Americans: indeed, his reflection on teaching in "The New South" portrays the families of his students as nearly always heroic and admirable, doing the best they can amidst continual violence and resource theft. And in that essay, as in his early and later reflections on the "talented tenth," there is a sense in which the moral and political work of schools provides things that the family simply cannot provide. An education in the humanities and the African American tradition is possible in a school in a way that is not possible in a family home-indeed, Du Bois sent his daughter to Fisk. And so, like Dewey and Durkheim, Du Bois insists that schools are a place of moral, political, and civic growth, not necessarily in opposition to family but as distinct from family.

Each of these authors emphasizes that schools are perhaps most fundamentally places of moral development, and moral in the broadest, Aristotelian sense of the way a life ought to be lived, as opposed to the more discrete sense of ethical action found in either Kantian deontology or English utilitarianism. As a result, also like Aristotle, there is no easy way to distinguish between the political and the moral. For Aristotle and for these three authors, to be moral is to determine how to live well, to live well is necessarily to live amongst others, and to determine how to live well among others is the fundamental question of politics. Both Dewey and Durkheim explicitly criticize Kant and the Utilitarians for moral systems rooted in discrete, individual decisions, in contrast to their more expansive sense of the social nature of the moral-political (The Deontologists clearly have a sense of the social goods of moral decisions, but their orientation is still rooted in aggregate individuals). While both Dewey and Durkheim are ambivalent about their connection to Aristotle, and both preceded significantly the mid twentieth-century neo-Aristotelian turn of virtue ethics led by Phillipa Foot and G.E.M. Anscombe, they nonetheless emphasize a more Aristotelian-if-not-byname focus on what would become a central tenet of virtue ethics: the point of ethical behavior is less the right than the good, an emphasis less on what you should do and more how you should live. While DuBois is less explicit in his concern about specifically engaging competing moral philosophical traditions, he certainly knew them, and his emphases on moral education can be read as equally Aristotelean. Du Bois is certainly profoundly aware of the connection between morals and politics in discussions of education.

Of the three, Durkheim is the closest to being a Kantian, and the influence of Kant is clear throughout his writing, especially in Moral Education. As with his relationship to Kant's epistemology in The Elementary Forms of Religious Life (Durkheim 2008, Rawls 1996), Durkheim's relationship to Kant's ethics are ambivalent. Durkheim's moral realism (McCaffree 2019), like his conception of the Kantian categories in Elementary Forms, are a form of conventional realism, or socially-situated realities with the weight and power of the fundamental. While Durkheim acknowledges the sacredness of the individual in a modern, secular society, it is nonetheless the case that individual motives for individual ends are at best amoral, a case he makes in explicit contrast to Utilitarians (1961: 57-58). As such, people's moral commitments must be to society itself as something emergent beyond the aggregate "sum of self-interests," allowing Durkheim to construct a quasi-Kantian 
"Why Study Schools?" by Jeffrey Guhin forthcoming in The Handbook of Classical Sociological Theory, published by Springer and edited by Seth Abrutyn and Omar Lizardo.

maxim, "man [sic] acts morally only when he works toward goals superior to, or beyond, individual goals, only when he makes himself the servant of a being superior to himself and to all other individuals" (1961: 60). Durkheim dismisses God as such an individual, and so all that remains is society itself. This moral capacity, contrary to Kant, is neither transcendent nor deferent to reason (1961: 110): morality is rather an emergent social experience, rooted in society itself and felt with a religious urgency once described with religious language and now explained in the language of social science.

Durkheim's ambivalent relationship to Kant is most marked in their respective relationships to discipline. Kant's obsession with autonomy as the center point of moral life makes him nervous about the process of education itself, something that seems almost necessarily coercive and therefore contrary to the goal of brining students to their own moral agency. The problem is not altogether similar from Rousseau's reflections on how he would bring his imaginary student Emile to a sense of self-love that is marked by discipline, restraint, and a capacity for future goals rather than indulgence, sloth, and impulsive inattention. Rousseau was an important influence on both Kant and Durkheim, but whereas Rousseau's insistence that children must be "forced to be free" was a point of opposition for Kant, it forms, in some sense, the central thesis of Durkheim's emphasis on discipline in his own study of moral education.

For Durkheim, "Discipline is itself a factor, sui generis, of education. There are certain essential elements of moral character that can be attributed only to discipline" (1961: 43): echoing Aristotle and Plato as much as Kant and Rousseau, Durkheim describes how the rigors of discipline allow children to become autonomous; discipline teaches freedom from passions rather than servitude to them. One of the ongoing tensions in any study of the philosophy of education is the location of this discipline: is it within the teacher, within the student, or within the rules themselves? Durkheim is somewhat vague in his answer to this question, though he seems to assume that the primary answer is that the rules themselves are the manifestation of a moral discipline whose ultimate source is society itself, and the vivacious experience of social life. The most important role of the educator, he writes, is to "give the child the clearest possible idea of the social groups to which he [sic] belongs." And not only to learn, for "to learn the love of collective life we must live it; not only in our minds and imaginations, but in reality" (1961: 228-229) through emphasizing both the school environment itself and the conduct of the classes themselves. Referring regularly to "our class," emphasizing collective punishments and rewards, as well as student agreement with individual punishments or rewards, and changing teachers regularly all while maintaining a coherent school culture: each of these helps Durkheim to build resources for how a school can impart morality in a way that will be helpful for students to become anonymous individuals in a society that requires a moral commitment to the collective. As such, even a teacher's discipline must be understood as beholden to "a moral power superior to him [sic]" (1961: 156) to which the teacher is just as obliged as the students. It is vital that students not confuse the teacher's power for the power of moral life, just as they lean not to confuse what they want at a given moment for what would actually make them (and their society) happy.

Like Durkheim, Dewey has read his Plato and Rousseau, and he is just as interested in how people become free of their passions. The difference is that Dewey takes these old debates and recasts them in his own philosophical language. For Dewey, passions and emotions are interesting enough, but the central philosophical question is habits, those that control people, and those that people control. Habits is a broad and widely expansive category. If Durkheim views a kind of collective flourishing as the great good of education, then for Dewey the goal is the rather amorphous concept 
"Why Study Schools?" by Jeffrey Guhin forthcoming in The Handbook of Classical Sociological Theory, published by Springer and edited by Seth Abrutyn and Omar Lizardo.

of "growth," something that is only possible of habits are "active," involving "thought, invention, and initiative in applying capacities to new aims" as opposed to the routine that "marks the arrest of growth" (2007: 44).

Dewey does not deny that something resembling formal discipline can at times be necessary, but he believes these attempts at structure too often force a kind of routine that can alienate students from the broader possibilities of their actions. His technical definition of education emphasizes the importance of meaning in these accounts: "It is that reconstruction or reorganization of experience which adds to the meaning of experience and which increases ability to direct the course of subsequent experience" (2007: 61). The point is not a total abandonment of discipline, as he makes clear in his criticism of progressive schools, but rather to center experiences and interactions over any form of "dictation" whether child-directed or adult-directed; when school communities create a curriculum in which students can feel invested and come to recognize their own lack of capacity, teachers can become "natural leaders" in efforts towards growth (1940: 216-223).

The moral goal of such growth is at first less explicit here than it is for Durkheim, until the reader comes to realize that an openness to growth and to a relative flexibility regarding habits is central to Dewey's conception of the moral project of democracy. For him, democratic education is not only about educating people so they are sufficiently literate and numerate to engage in politics, neither is it even encouraging them to think for themselves and to be suspicious of any external authority as a dogmatic end of its own. The "deeper explanation," he writes, is to prepare people for "a mode of associated living" that is more than simply a form of government; it is a way of living in a pluralistic society in which different races, classes, and national origins (he does not mention sex, gender, or religion here) come together to "put a premium on variation in...action" (2007: 68). In the final chapter of Democracy and Education, Dewey makes clear that "the moral and the social quality of conduct are, in the last analysis, identical with each other...the measure of the worth of the administration, curriculum, and methods of instruction of the school is the extent to which they are animated by a social spirit" (2007: 261). Similarly, he argues that "to possess virtue...means to be fully and adequately what one is capable of becoming through association with others in all the offices of life" (2007: 261). Democratic education is moral education, and it is a kind of moral education rooted fundamentally not in students' shortcomings but in their capacity to grow with each other within a pluralistic society. Like Durkheim, Dewey is fascinated by the heterogeneity of modern social life, but while Durkheim sees it as a problem for robust moral commitments, Dewey views it as a solution.

To the extent either views themselves as solving a "deficit," it is not of the students themselves but of the methods of instruction and, by extension, a wider society that views the schooling of individuals as the solution to a problem caused, at least in part, by atomistic individualism. Durkheim rejects Kant and the Utilitarians towards a socially-mediated communitarianism, albeit one with respect for the individual — indeed it is more or less united by this respect. Dewey also explicitly engages his different from Kant and the utilitarians, and also towards something like a focus on the social rather than the individual, whether in the aggregate (utilitarians) or the radically autonomous (Kant). Yet if Durkheim's focus on the moral good of education is in internalizing the moral power of the collective, then Dewey emphasizes the moral good of the interaction, of the moment, any moment, that can help us to re-evaluate our habits towards greater individual and collective growth. 
"Why Study Schools?" by Jeffrey Guhin forthcoming in The Handbook of Classical Sociological Theory, published by Springer and edited by Seth Abrutyn and Omar Lizardo.

Du Bois shares these critiques of individualism, but he brings a focus on race entirely unexamined by Durkheim and given insufficient attention by Dewey. Yet, like Durkheim and Dewey, he rejects an individualist frame for understanding education and its purpose, and he imbues education with a deep moral purpose less centered on society writ large and more focused on undoing the harm done to African Americans. A college, he writes in a 1924 speech, must be marked by freedom of spirit, self-knowledge, and a recognition of truth, with a maternal sense of care described in the Latin phrase, Alma Mater. Black students, he writes, come out of the Valley of the Shadow with souls that have been hurt and crushed, and the great duty of the Negro college is to say to these students that the little sordid things of earth and of ordinary life where they lack so much freedom, are as nothing compared with the great realms of the spirit" (Westbrook 2014: 171).

In his re-evaluation of his famous call for a talented tenth, Du Bois describes how his experience at a Black university was full of discussion of character, while it was considered bad taste to discuss character education at Harvard, and entirely forgotten in Berlin. Indeed, despite his reorientation towards Marxism and a growing suspicion of the aristocratic underpinnings of the talented tenth concept, Du Bois nonetheless insists that "there still remains that fundamental and basic requirement of character for any successful leadership toward great ideals" (Westrbrook 2014: 205).

This commitment to character towards greater ideals is not a question of Black American's "deficits" but rather the explicit racism which Black American have endured. "If the Negro public school system had been sustained, guided, and supported, the American Negro today would equal Denmark in literacy," Du Bois writes in Black Reconstruction in America. Despite the marginalization and violence inflicted upon Black public schools and colleges, Black Americans in Reconstruction felt "an intense desire to rise out of their condition by means of education" (1992: 637-638). That intense desire would continue in Du Bois's own time, as he described in Souls of Black Folk, and still with this moral edge, not only of education in morality, but of education as itself a moral good that serves as a critique of white racism. In a powerful response to the white Southern Gentleman, Du Bois describes how such a white gentleman might "fasten crime upon this race as a peculiar trait," yet "the masses of Negroes" will respond that "slavery was the arch-crime, and lynching and lawlessness its twin abortion, that color and race are not crimes, and yet they it is which in this land receives most unceasing condemnation, North, East, South, and West" (1994: 48)

It is this struggle against condemnation that motivates Du Bois's sense of double consciousness, of constantly being aware of how you are seen by an oppressor and how you are seen by yourself, or those like you. Yet it is this condemnation that also presents education as the only real solution to problem of racial oppression, and while industrial and vocational education is a start, it is insufficient. "The foundations of knowledge in this race, as in others, must be sunk deep in the college and university if we would build a solid, permanent structure." He continues that while the Negro college has many purposes, it must, "beyond all this, develop men," by which he means a "higher individualism... a loftier respect for the sovereign human soul that seeks to know itself and the world about it; that seeks a freedom for expansion and self-development; that will love and hate and labor in its own way, untrammeled alike by old and new" (1994: 48-49). Contained within this commitment is both a call for aesthetic self-fashioning and a broader moral commitment to both fellow African-Americans and to their place in society. To the extent Du Bois recognizes a moral "deficit" which must be filled by education, it is the wide moral hole of racism.

As a result, each of the authors also suggests a politics that can be described as liberal but that goes well beyond the kind of procedural liberalism lambasted by communitarian critiques. In each author, 
"Why Study Schools?" by Jeffrey Guhin forthcoming in The Handbook of Classical Sociological Theory, published by Springer and edited by Seth Abrutyn and Omar Lizardo.

there is a responsibility to the social group that goes well beyond the harm principle described by John Stuart Mill. In other words, Durkheim's commitment to the collective and Du Bois's insistence on Black solidarity and the need for white recompense both manifest a politics manifested as much by moral responsibilities as much as commonly-agreed upon rights. The one exception to this might be Dewey, whose commitment to growth can be read as individualistic. Yet for Dewey, an individual only exists because of interactions with others; the self and the society are in continual flux, and even the society is probably too broad of a term, as he would prefer to describe the more local institutions and organizations with which an individual interacts. He ends his book, Individualism: Old and New with a nod to Candide: "Our garden is the world, in the angle at which it touches our own manner of being... we who are also parts of the moving present, create ourselves as we create an unknown future (1999: 83). As Robert Westbrook (2015) and other Dewey scholars (Chambliss 1987, Ryan 1997, Savage 2002, Shusterman 1994, Teehan 1995) have suggested, Dewey is very much a liberal, but a liberal with a sense of the robust tradition and moral commitments liberalism requires, more akin to the Emersonian liberalism of Stanley Cavell (2003) than the impoverished liberalism decried by communitarians like Alasdair MacIntyre (1984).

\section{Against the Veneer of Meritocracy and Towards Internal Goods}

Each of these authors emphasizes the goods internal to education, rather than the external goods they might eventually produce. In so doing, they provide a powerful counter to a particularly American reading of meritocracy, or the idea that all people eventually get to their role and status in society based entirely on their own merit, which is usually related, though not by any means identical, to their achievement. Critiques of meritocracy abound in sociology, particularly the sociology of education. Most of these critiques do not take explicit issue with the legitimacy of merit as an organizing principle; instead they take issue with how the language of meritocracy obfuscates enduring inequalities and allows privilege to present itself as achievement (Khan and Jerolmack 2013). Indeed, few of the recent prominent critiques of meritocracy (Arrow, Bowles, and Durlauf 2018, Castilla 2008, McCoy and Major 2007, McNamee and Miller 2009) take explicit issue with the concept of merit in and of itself. The problem is not that merit might justify differing roles and statuses in society. The problem is, first, simply one of misrecognition: those with just as much merit are ignored because of a variety of social mechanisms, many of them having to do with class, race, and gender. And the second problem is a broader and more existential one, best worked out in the work of Pierre Bourdieu $(1984,1998)$ though also clear in the education writings of Paul Willis (1977) and Basil Bernstein: for these theorists, the misrecognition of meritocracy goes much deeper than passing people up for jobs. It is rooted in the very nature of our evaluations, of what we deem as important and praiseworthy, in the "rules of the game." In this deeper critique of meritocracy, it might well be the case that X or Y person or group or social type "merits" a job more than others, but the deeper and more important question is why that kind of merit is the kind we deem most essential.

One of the ongoing challenges for the sociology of education is how to handle this radical critique of its underlying normative goals. What, precisely, does the sociology of education want? Both greater equality and more consistent equity seem like obvious answers, though equality and equity of what? And what might be the sources? As I have described above, too often the sociology of education is at best agnostic and at worst explicitly part of the process of assuming that education is the best tool to remedy longstanding inequalities and inequities. Of course, having better schools certain has the potential to decrease the wide variety of gaps (wealth, income, test scores, health, etc.) that are correlated with educational outcomes, at least for particular individuals. Yet few 
"Why Study Schools?" by Jeffrey Guhin forthcoming in The Handbook of Classical Sociological Theory, published by Springer and edited by Seth Abrutyn and Omar Lizardo.

believe schools are a magic bullet to solve everything, even if believing they are so is a convenient way to maintain a commitment to the myth of merit while enjoying the benefits of rampant and ever-expanding inequality.

Dewey, Durkheim, and Du Bois are all especially helpful here. All three insist that some form of social redistribution is the way to solve inequality, and distribution much more robust than simply waiting for rich people give their extra money to the school district of their choice. Du Bois and Durkheim both identified as socialists, while Dewey probably would consider himself something like what we would now call a "European social democrat." Yet for any of them, there is a sense that economic redistribution entails more than education, and even more than a universal commitment to education (e.g. no longer linking education funding to property taxes thereby necessarily radically distinguishing funding amounts). Simply put, for these three, education is not the way to make the poor no longer poor. The government has other, better means to accomplish those tasks. Dewey is quite explicit about this distinction throughout his work, especially in Democracy and America.

Durkeim does not make this point explicitly in Moral Education, but his other writings on socialism make clear that he does not believe education (and with it the veneer of meritocracy) is the way to make society more just, at least not via the economic outcomes schools might produce. The way to make society more just, for Durkheim, is not by ensuring students have skills to make money; it is by ensuring students have the skills to live together well.

And living together well means learning to recognize not only our differences but also the sources of our differences. And it here where Du Bois captures something both Dewey and Durkheim miss, though Dewey gets a bit closer than Durkheim. Dewey does see the importance of bringing together a multicultural society and he is, especially for his time, sensitive to how such integration can lead to minority groups losing their sense of self, of being force to dilute themselves into a "melting pot" whose "flavor" will be dominated by those with power. Writing at a time of massive immigration and massive protest to that immigration, Dewey wants to make sure people with marginalized identities are able to maintain those identities even as they become part of the American classroom and part of the American community. Yet Dewey is nonetheless not as capable as Du Bois at recognizing the magnitude of racial oppression, and with it the specific challenges of particular communities, especially African Americans, but by extension, virtually any group who, through a process of marginalization, experiences American through a kind of "double consciousness."

Yet for all three of these authors, there is a sense that schools exist not for economic uplift (which should be provided elsewhere) but rather for goods that can only be gained within schools. And some of that good is, of course, learning about things, and learning about them in a way that engages the student-teacher relationship and the relationships between students. But another, quite significant piece of that development is through students coming to recognize within their relationships to their teachers, to each other, and to themselves something fundamental about their lives. Schools are places with people, and those people are more than an aggregate of individuals to be measured and evaluated and prepared for a life to come afterwards. Students at any level of school are always already political, moral, and social beings. Dewey, Durkheim, and Du Bois help us to recognize the importance of this recognition. It's up to us to do something with that recognition. 
"Why Study Schools?" by Jeffrey Guhin forthcoming in The Handbook of Classical Sociological Theory,

Bibliography

Abend, Gabriel. 2014. The moral background: an inquiry into the history of business ethics. Princeton: Princeton University Press.

Alcoff, Linda Martín. 2005. Visible identities: Race, gender, and the self. New York: Oxford University Press.

Arrow, Kenneth, Samuel Bowles, and Steven N Durlauf. 2018. Meritocracy and economic inequality. Princeton: Princeton University Press.

Au, Wayne. 2010. Unequal by design: High-stakes testing and the standardization of inequality. New York: Routledge.

Bargheer, Stefan. 2018. Moral entanglements: Conserving birds in Britain and Germany. Chicago: University of Chicago Press.

Barnes, Elizabeth. 2016. The minority body: A theory of disability. New York: Oxford University Press.

Berman, Elizabeth Popp. 2011. Creating the market university: How academic science became an economic engine. Princeton: Princeton University Press.

Boli, John, Francisco O Ramirez, and John W Meyer. 1985. "Explaining the origins and expansion of mass education." Comparative Education Review 29 (2):145-170.

Bourdieu, Pierre. 1984. Distinction: A Social Critique of the Judgement of Taste. Translated by Richard Nice. Cambridge: Harvard University Press.

Bourdieu, Pierre. 1990. The Logic of Practice. Translated by Richard Nice. Stanford: Stanford University Press.

Bourdieu, Pierre. 1998. The state nobility: Elite schools in the field of power. Translated by Lauretta C. Clough. Stanford: Stanford University Press.

Bourdieu, Pierre, and Jean-Claude Passeron. 1977. Reproduction in Education, Society and Culture. Translated by Richard Nice. London: Sage Publications.

Bowles, Samuel, and Herbert Gintis. 1976. Schooling in capitalist America. Vol. 57: New York: Basic Books.

Brint, Steven. 2013. "The 'Collective Mind' at work: A decade in the life of US Sociology of Education." Sociology of Education 86 (4):273-279.

Buchmann, Claudia, Thomas A DiPrete, and Anne McDaniel. 2008. "Gender inequalities in education." Annual Review of Sociology. 34: 319-337.

Calarco, Jessica McCrory. 2018. Negotiating Opportunities: How the Middle Class Secures Advantages in School: Oxford University Press.

Campbell, David E, and Richard G Niemi. 2016. "Testing civics: State-level civic education requirements and political knowledge." American Political Science Review 110 (3):495-511.

Castilla, Emilio J. 2008. "Gender, race, and meritocracy in organizational careers." American Journal of Sociology 113 (6):1479-1526.

Cavell, Stanley. 2003. Emerson's transcendental etudes. Stanford: Stanford University Press.

Chambliss, Joseph James. 1987. Educational theory as theory of conduct: From Aristotle to Dewey. Albany, NY: SUNY Press.

Collins, Patricia Hill, and Sirma Bilge. 2016. Intersectionality. Malden, MA: Polity Press.

Collins, Randall. 2019. The credential society: An historical sociology of education and stratification. New York: Columbia University Press.

Covington, Martin V. 2000. "Intrinsic versus extrinsic motivation in schools: A reconciliation." Current directions in psychological Science 9 (1):22-25.

Dewey, John. 1940. Education Today. Ed. Joseph Ratner. New York: G. P. Putnam’s Sons.

Dewey, John. 2007. Democracy and Educaiton. New York: The Free Press. 
"Why Study Schools?" by Jeffrey Guhin forthcoming in The Handbook of Classical Sociological Theory,

published by Springer and edited by Seth Abrutyn and Omar Lizardo.

Downey, Douglas B. 2008. "Black/White differences in school performance: The oppositional culture explanation." Annual Review of Sociology 34:107-126.

Downey, Douglas B, and Dennis J Condron. 2016. "Fifty years since the Coleman Report: Rethinking the relationship between schools and inequality." Sociology of Education 89 (3):207220.

Du Bois, W.E.B. 1994. The Souls of Black Folk. Mineola, NY: Dover Publications.

Du Bois,W.E.B. 2014. Black Reconstruction in America): An Essay Toward a History of the Part Which Black Folk Played in the Attempt to Reconstruct Democracy in America, 1860-1880. New York: Oxford University Press.

Duckworth, Angela. 2016. Grit: The power of passion and perseverance. Vol. 234: Scribner New York, NY.

Durkheim, Emile. 1961. Moral education. Translated by Everett K. Wilson and Herman Schnurer. New York: Free Press.

Durkheim, Emile. 1995. The Elementary Forms of the Religious Life. Translated by Karen Fields. New York: Free Press.

Dweck, Carol S. 2008. Mindset: The new psychology of success. New York: Random House.

Eliasoph, Nina. 2013. Making volunteers: civic life after welfare's end. Princeton: Princeton University Press.

Ferguson, Ann Arnett. 2001. Bad boys: Public schools in the making of black masculinity. Ann Arbor: University of Michigan Press.

Fields, Jessica. 2008. Risky lessons: Sex education and social inequality. New Brunswick, NJ: Rutgers University Press.

Guhin, Jeffrey. 2016a. "Why sociologists of education are moral (personally) but don't write about morality (professionally): a cultural sociology of education." Sociologia e Politiche Sociali 2: 3451.

Guhin, Jeffrey. 2016b. "Why Worry about Evolution? Boundaries, Practices, and Moral Salience in Sunni and Evangelical High Schools." Sociological Theory 34 (2):151-17.

Guhin, Jeffrey, and Joseph Klett. 2018. "Internal Goods in the Sociology of Education: Skills, Habits, Virtues, and the Problem of Power." Socarxiv. Last Modified April 20, 2022. https://osf.io/preprints/socarxiv/sv23y/

Hall, Peter A, and David Soskice. 2001. Varieties of Capitalism. New York: Oxford University Press.

Hallett, Tim. 2010. "The myth incarnate: Recoupling processes, turmoil, and inhabited institutions in an urban elementary school." American Sociological Review 75 (1):52-74.

Harrison, Peter. 2011. "Adam Smith and the history of the invisible hand." Journal of the History of Ideas 72 (1):29-49.

Hirschman, Daniel, and Elizabeth Popp Berman. 2014. "Do economists make policies? On the political effects of economics." Socio-Economic Review 12 (4):779-811.

Holm, Anders, Mads Meier Jæger, Kristian Bernt Karlson, and David Reimer. 2013. "Incomplete equalization: The effect of tracking in secondary education on educational inequality." Social science research 42 (6):1431-1442.

Hooker, Juliet. 2016. "Black Lives Matter and the paradoxes of US Black politics: From democratic sacrifice to democratic repair." Political Theory 44 (4):448-469.

Ispa-Landa, Simone. 2013. "Gender, race, and justifications for group exclusion: Urban Black students bussed to affluent suburban schools." Sociology of Education 86 (3):218-233.

Itzigsohn, José, and Karida L Brown. 2020. The Sociology of WEB Du Bois: Racialized Modernity and the Global Color Line. New York: NYU Press.

Joas, Hans. 1996. The creativity of action. Chicago: University of Chicago Press. 
"Why Study Schools?" by Jeffrey Guhin forthcoming in The Handbook of Classical Sociological Theory,

Johnston, James Scott. 2007. "Right and goods: Procedural liberalism and educational policy." Educational Theory 57 (4):469-488.

Khan, Shamus, and Colin Jerolmack. 2013. "Saying meritocracy and doing privilege." The Sociological Quarterly 54 (1):9-19.

Kuhn, Thomas. 1962. The Structure of Scientific Revolutions. Chicago: University of Chicago Press.

Labaree, David F. 1999. How to succeed in school without really learning: The credentials race in American education: Yale University Press.

MacIntyre, Alasdair. 1984. After Virtue. Notre Dame: Notre Dame University Press.

Mason, Andrew. 2000. Community, solidarity and belonging: Levels of community and their normative significance. New York: Cambridge University Press.

Mayrl, Damon. 2016. Secular Conversions: Political Institutions and Religious Education in the United States and Australia, 1800-2000. New York: Cambridge University Press.

McCaffree, Kevin. 2019. "Moral Realism in Historical Sociological Theory." Journal of Historical Sociology 32 (1):124-141.

McCoy, Shannon K, and Brenda Major. 2007. "Priming meritocracy and the psychological justification of inequality." Journal of experimental social psychology 43 (3):341-351.

McNamee, Stephen J, and Robert K Miller. 2009. The meritocracy myth. Lanham: Rowman \& Littlefield.

Mead, George Herbert. 1967. Mind, Self, and Society. Chicago: University of Chicago Press.

Mehta, Jal. 2015. The allure of order: High hopes, dashed expectations, and the troubled quest to remake American schooling: New York: Oxford University Press.

Mehta, Jal, and Scott Davies. 2018. "Education in a New Society: Renewing the Sociology of Education." In Education in a New Society: Renewing the Sociology of Education, edited by Jal Mehta and Scott Davies, 1-33. Chicago: University of Chicago Press.

Meyer, Heinz-Dieter, and Brian Rowan. 2006. "Institutional analysis and the study of education." In The new institutionalism in education, edited by Heinz-Dieter Meyer and Brian Rowan, 1-13.

Albany, NY: State University of New York Press.

Meyer, John W. 1977. "The effects of education as an institution." American Journal of Sociology 83 (1):55-77.

Meyer, John W. 2010. "World society, institutional theories, and the actor." Annual review of sociology $36: 1-20$.

Meyer, John W, and Ronald L Jepperson. 2000. "The 'actors' of modern society: The cultural construction of social agency." Sociological theory 18 (1):100-120.

Mill, John Stuart. 2015. On Liberty, Utilitarianism, and other essays: Oxford University Press, USA.

Mittleman, Joel. 2018. "A downward spiral? Childhood suspension and the path to juvenile arrest." Sociology of education 91 (3):183-204.

Morris, Aldon. 2017. The scholar denied: WEB Du Bois and the birth of modern sociology. Oakland: University of California Press.

Moses, Wilson Jeremiah. 1988. The golden age of Black nationalism, 1850-1925. New York: Oxford University Press on Demand.

Nunn, Lisa M. 2014. Defining student success: The role of school and culture. New Brunswick: Rutgers University Press.

Owens, Ann. 2018. "Income segregation between school districts and inequality in students' achievement." Sociology of Education 91 (1):1-27.

Owens, Jayanti, and Scott M Lynch. 2012. "Black and Hispanic immigrants' resilience against negative-ability racial stereotypes at selective colleges and universities in the United States." Sociology of Education 85 (4):303-325. 
"Why Study Schools?" by Jeffrey Guhin forthcoming in The Handbook of Classical Sociological Theory,

published by Springer and edited by Seth Abrutyn and Omar Lizardo.

Pascoe, Cheri J. 2011. Dude, you're a fag: Masculinity and sexuality in high school. Berkeley: University of California Press.

Pateman, Carole, and Charles Mills. 2007. Contract and domination. Malden, MA: Polity.

Raudenbush, Stephen W, and Robert D Eschmann. 2015. "Does schooling increase or reduce social inequality?" Annual Review of Sociology 41:443-470.

Rawls, Anne Warfield. 1996. "Durkheim's epistemology: the neglected argument." American Journal of Sociology 102 (2):430-482.

Ryan, Alan. 1997. John Dewey and the high tide of American liberalism. New York: WW Norton \& Company.

Sandel, Michael J. 1984. "The procedural republic and the unencumbered self." Political Theory 12 (1):81-96.

Sandel, Michael J. 1998. Liberalism and the Limits of Justice. New York: Cambridge University Press.

Savage, Daniel M. 2002. John Dewey's liberalism: individual, community, and self-development. Carbondale: Southern Illinois University Press.

Shelby, Tommie. 2005. We who are dark: The philosophical foundations of black solidarity. Cambridge: Harvard University Press.

Shusterman, Richard. 1994. "Pragmatism and liberalism between Dewey and Rorty." Political Theory $22(3): 391-413$.

Smith, Adam. 2010. The Wealth of Nations..

Stevens, Mitchell L. 2008. "Culture and education." The ANNALS of the American Academy of Political and Social Science 619 (1):97-113.

Taylor, Paul C. 2004. "What's the use of calling Du Bois a pragmatist?." Metaphilosophy 35(1-2): 99114.

Teehan, John. 1995. "Character, integrity and Dewey's virtue ethics." Transactions of the Charles $S$. Peirce Society 31 (4):841-863.

Westrbook, Randall. (Ed.) 2014. Education and Empowerment: The Essential Writings of W.E.B. Du Bois. East Brunswick NJ: Hansen Publishing Group.

Westbrook, Robert B. 2015. John Dewey and american democracy. Cornell University Press.

Willis, Paul E. 1977. Learning to labor: How working class kids get working class jobs: Columbia University Press.

Winchester, Daniel, and Jeffrey Guhin. 2019. "Praying "Straight from the Heart”: Evangelical sincerity and the normative frames of culture in action." Poetics 72:32-42. 